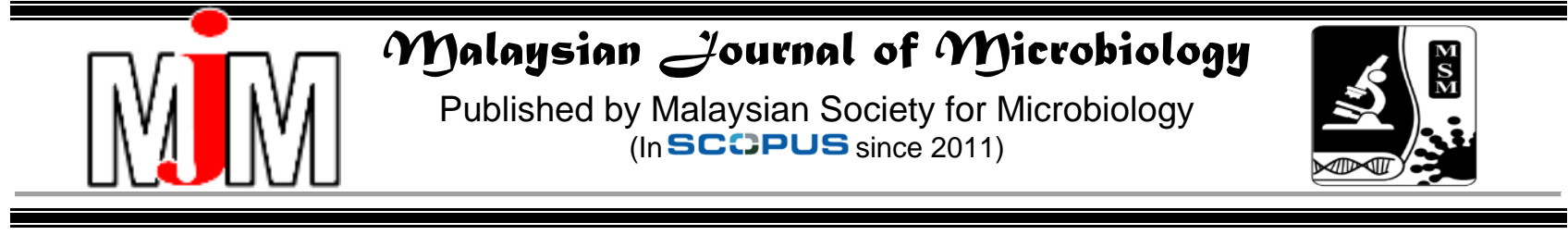

\title{
Antibacterial stability of Spondias pinnata (L. f.) Kurz leaves extract and its mechanism
}

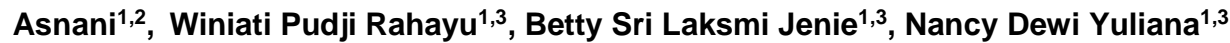 \\ ${ }^{1}$ Department of Food Science and Technology, Bogor Agricultural University, Kampus IPB Darmaga 16680, Bogor, \\ Indonesia. \\ 2Department of Aquatic Products Technology, Halu Oleo University Kendari, Kampus Hijau Bumi Tridharma, Anduonohu \\ 93132, Kendari, Indonesia. \\ ${ }^{3}$ Southeast Asian Food and Agricultural Science and Technology (SEAFAST) Centre, Bogor Agricultural University, \\ LPPM - Bogor Agricultural University, Kampus IPB Darmaga 16680, Bogor, Indonesia. \\ Email wini_a@hotmail.com
}

Received 11 August 2017; Received in revised form 28 June 2018; Accepted 28 June 2018

\begin{abstract}
Aims: This study was conducted to observe the stability of Spondias pinnata leaf (SPL) extract antibacterial at different $\mathrm{pH}$, salt concentration and temperature, to examine its antibacterial effectivity on minced fish, and to determine its fraction's antibacterial mechanism.

Methodology and results: The tested SPL ethanolic extract, n-hexane, chloroform, ethyl acetate and water fractions' antibacterial activity against Bacillus cereus and Vibrio parahaemolitycus. Its stability against $\mathrm{pH}$, salt, and thermal variation was studied, as well as the mechanism and application in fish. Ethyl acetate fraction and water fraction showed the highest activity against $B$. cereus (MIC $0.62 \mathrm{mg} / \mathrm{mL}$ ). Protein profile analysis using gel electrophoresis showed that $B$. cereus cells exposed with SPL ethyl acetate fraction and water fraction showed thinner protein bands as compared to control. Severe damage of the cells treated with 3 MIC was also observed under SEM. Antibacterial activity of SPL ethanolic against Bacillus cereus and Vibrio parahaemolitycus were stable against heat treatment $\left(80-121^{\circ} \mathrm{C}\right.$ for 15 $\mathrm{min})$ and $\mathrm{NaCl}$ treatment $(0-10 \% \mathrm{w} / \mathrm{v})$, whereas the inhibition zone respectively at $\mathrm{pH} 4(10.31 \pm 0.25$ and $8.09 \pm 0.97 \mathrm{~mm})$ was higher than $\mathrm{pH} 7(8.45 \pm 0.52$ and $6.66 \pm 1.84 \mathrm{~mm})$. Application of SPL ethanolic extract in fish broth showed higher antibacterial activity than in fish flesh, which gave bactericidal effect at 3 MIC.
\end{abstract}

Conclusion, significance and impact study: Ethanol extract can be developed as a natural preservative in fish processing.

Keywords: Antibacterial activity, antibacterial mechanism, antibacterial stability, Spodias pinnata

\section{INTRODUCTION}

Fish is a good medium for bacterial growth such as Bacillus cereus and Vibrio parahaemolyticus, both are known as food poisoning microbes. In United States during 1998-2004, there were 2 cases of food poisoning associated with seafood consumption caused by $B$. cereus and 25 cases caused by $V$. parahaemolyticus out of a total of 644 microbes related seafood poisoning cases (NACMCF, 2008). Several studies reported some cases of $B$. cereus and $V$. parahaemolyticus contamination in fish. Elhadi et al. (2016) reported that $9.4 \%$ of fish imported from Asian countries that were marketed in Saudi Arabia was contaminated by B.cereus. Noorlis et al. (2011) reported that the prevalence of Vibrio spp and $V$. parahaemolyticus contamination in catfish and red nile tilapia sold in hypermarkets in Malaysia reached as much as $98.67 \%$ and $24 \%$ respectively.

The shelf life of fishery products can be extended by cooling and freezing processes, and both methods are good at preserving texture and taste for a long time. To further extend the shelf life, combining cooling techniques and natural antibacterial applications can be done. Abdollahzadeh et al. (2014) evaluated the antilisterial activity of thyme EO (essential oil) in minced fish during refrigerated storage. The addition of thyme EO at 0.8 or $1.2 \%$ to minced fish meat exhibited a strong antilisterial activity during storage. The addition of EO at $1.2 \%$ showed a higher effect against $L$. monocytogenes than the addition at $0.8 \%$ during refrigerated storage. The strong antilisterial activity of thyme oil is often attributed to a high percentage of phenolic compounds. 
Spondias pinnata (Anacardiaceae), also known as wild mango or hog-plum, scattered in primary and secondary forest in Indonesia, Africans normally use SPL as an antipyretic, antihelmintic, anti-inflammatory and antidiarrhea (Muhammad, 2013). In Indonesia, SPL is usually consumed as fresh vegetables, while in Southeast Sulawesi SPL is a popular herb to improve the taste of meat or fish.

There are only a few reports on $S$. pinnata leaves antibacterial activities. Jain et al. (2014) tested ethanolic extract of the plant against 8 Gram-positive and Gramnegative bacterial strains. The result indicated that they could inhibit all tested bacteria with the inhibition zone ranged between $8.33 \pm 1.53-28.67 \pm 0.58 \mathrm{~mm}$ with the lowest MIC value was againsts $S$. aureus $(2.0 \mathrm{mg} / \mathrm{mL})$. The exact mechanism of this antibacterial action has not been widely documented. In general, the mechanism of microbial inhibition by antimicrobial compounds could be divided into: (1) disruption againsts the cell wall components, (2) reactions of cell membranes resulting on changes in permeability and cell components loss, (3) inhibition of protein synthesis, and (4) disruption to the function of genetic material (Davidson, 2001).

In this research, we extracted SPL leaves using ethanol then fractionated it using $n$-hexane, chloroform, ethyl acetate and water. Antibacterial activity of all extract and fractions were tested against $B$. cereus and $V$. parahaemolyticus. The most active one was applied as antibacterial in fish broth and minced fish. Their antibacterial activity stability against thermal, salts, and $\mathrm{pH}$ variations was studied as well. To study the antibacterial mechanism, bacteria cells exposed to the most active fraction or extract were observed for morphological abnormalities using SEM and their protein profiles were observed using gel electrophoresis. The results of this research provided initial important information on the possibility to develop natural antibacterial compound from $S$. pinnata to be used as alternative preservative especially for fish and fish products.

\section{MATERIALS AND METHODS}

\section{Plant materials}

The leaves of Spondias pinnata (L.f. Kurz) was acquired from local gardens in Kambu, Kendari Regency and was identified at the "Herbarium Bogoriense", Research Center for Biology-Indonesian Institute of Sciences Bogor. Bacillus cereus ATCC 11778 and Vibrio parahaemolyticus ATCC 17802 as tested bacteria were obtained from National Agency of Drug and Food Control-Indonesia. Nile tilapia fish flesh (Oreochromis sp) was purchased from traditional market.

\section{Extraction and fractionation}

Spondias pinnata leaves was dried by oven at $40-45^{\circ} \mathrm{C}$ for 3-4 days until the leaves were light brown and brittle. The dried leaves were then powdered (size \pm 40 mesh) and stored at $-20{ }^{\circ} \mathrm{C}$ until used. Extraction process was conducted by dispersing SPL powder into ethanol (Merck) with 1:20 (w/v) ratio, following Parhusip et al. (2005) procedure with slight modification. The SPL powder $(50 \mathrm{~g})$ was added with ethanol $(500 \mathrm{~mL})$. Maseration aided by shaker was then performed at room temperature (28-30 $\left.{ }^{\circ} \mathrm{C}\right)$ for $1 \mathrm{~h}$, then sonicated for $45 \mathrm{~min}$ and macerated again with shake at room temperature for $1 \mathrm{~h}$. To obtain the filtrate, the solution was filtered using Whatman No.1 paper. The process was repeated by using $300 \mathrm{~mL}$ and $200 \mathrm{~mL}$ ethanol respectively and the filtrates were combined. The solvent were then evaporated using rotary evaporator at the temperature of $50{ }^{\circ} \mathrm{C}$ followed by flushing under nitrogen gas.

The ethanolic extract was fractionated using manual liquid-liquid sequential solvent extraction based on the method by Maser et al. (2015). Ethanol extract were dissolved in distilled water $(1: 30 \mathrm{w} / \mathrm{v})$ and partitioned gradually in separator funnel using n-hexane, chloroform, and ethyl acetate, respectively (Merck, $1: 1 \mathrm{v} / \mathrm{v}$ ratio). The process was repeated three times and the solvent was then evaporated using rotary evaporator at the temperature of $50-55^{\circ} \mathrm{C}$. All extract and fractions were kept refrigerated prior use.

\section{Antibacterial activity determination}

Antibacterial activity of the extract is determined by well diffusion method as previously performed by Chinnaiyan et al. (2013). Two bacteria (Bacillus cereus and Vibrio parahaemolyticus) were used. $100 \mathrm{mg}$ of SPL extract/fraction was dissolved into $1 \mathrm{~mL} 100 \%$ DMSO (Dimethyl sulfoxide; Merck). Tested bacteria were refreshed in MHB medium (Mueller Hinton Broth; Oxoid) until their population reached $10^{6}-10^{7} \mathrm{CFU} / \mathrm{mL}$. In $25 \mathrm{~mL}$ of MHA (Mueller Hinton order; Oxoid) $25 \mu \mathrm{L}$ of the fresh bacteria culture was inoculated, poured into a petri dish and allowed to harden. Six mm diameter wells were made on the agar. A $60 \mu \mathrm{L}$ of the extract/fraction was added into the wells. Chloramphenicol (1 $\mathrm{mg} / \mathrm{mL}$, Sigma) and $100 \%$ DMSO were used as a positive and negative control respectively. The Petri dish was incubated at $37^{\circ} \mathrm{C}$ for 18 $20 \mathrm{~h}$. Formed transparent zone was measured using a digital caliper (Nankai, Japan and after subtracted by the well diameter $(6 \mathrm{~mm})$, it was expressed as diameter of the inhibition zone (DIZ, $\mathrm{mm}$ ). The experiment was carried out using Completely Randomized Design (CRD) where each treatment was repeated 3 times.

\section{MIC (Minimum Inhibition Concentration) determination}

MIC value was determined according to a method described by Sadiq et al. (2015) with slight modification. $100 \mathrm{mg} \mathrm{SPL}$ extract/fraction was dissolved into $1 \mathrm{~mL}$ of $10 \%$ DMSO (Dimethyl sulfoxide) followed by ultrasonification and centrifugation to obtain the supernatant. Next, a series of two folds dilution was performed using sterile MHB with the volume of $1 \mathrm{~mL}$, to obtain a concentration of $1.56-50 \mathrm{mg} / \mathrm{mL}$ for the extract and $0.039-5 \mathrm{mg} / \mathrm{mL}$ for fractions, and $0.78-50 \mu \mathrm{g} / \mathrm{mL}$ for 
Chloramphenicol which was used as positive control. The tested bacteria were inoculated onto the sample. The mixtures were incubated at $37^{\circ} \mathrm{C}$ temperature for $18-20 \mathrm{~h}$. The lowest concentration of the extract/fraction that indicates no visible growth visually (appeared as a clear solution) was determined as MIC.

\section{Stability of antibacterial activity of $S$. pinnata leaves extract under various $\mathrm{pH}, \mathrm{NaCl}$ concentration and heating temperature}

Stability testing was conducted by a procedure previously performed by Naufalin et al. (2006). The stability test of SPL extract on $\mathrm{pH}$ was done by dissolving $100 \mathrm{mg}$ of SPL extract in $1 \mathrm{~mL}$ of phosphate buffer solution each with $\mathrm{pH}$ 4 and 7 . The stability test of SPL extract on $\mathrm{NaCl}$ was done by dissolving $100 \mathrm{mg}$ of SPL extract in $1 \mathrm{~mL}$ of $\mathrm{NaC}$ solution each with $0,2.5,5,7.5$ and $10 \%$ concentration. The stability test of SPL extract on heating temperature was done by dissolving $100 \mathrm{mg}$ of SPL extract in $1 \mathrm{~mL}$ of distilled water, then each heated at the temperature of 80 , 100 and $121^{\circ} \mathrm{C}$ for $15 \mathrm{~min}$. Measurement of antibacterial activities (DIZ) was performed against $B$. cereus and $V$. parahaemolyticus with a method previously described.

\section{Antibacterial activity determination of $S$. pinnata leaves ethanol extract on fish broth and minced fish}

Antibacterial activity in fish broth was conducted based on the method by Rialita (2014) with slight modifications. Fish broth was prepared by dispersing minced nile tilapia (Oreochromis sp.) into distilled water $(10 \% \mathrm{w} / \mathrm{v})$ and then sterilized. SPL ethanol extracts was added into the fish broth to obtain the concentration of extract 0 (control), 1, 3 and $5 \mathrm{MIC}$. As much as $5940 \mu \mathrm{L}$ broth was pipetted aceptically into sealed sterile vial. Fresh culture $(60 \mu \mathrm{L})$ of $B$. cereus and $V$. parahaemolyticus were inoculated into the broth (initial population were $10^{5}-10^{6} \mathrm{CFU} / \mathrm{mL}$ ). All samples were stored in a refrigerator at $5^{\circ} \mathrm{C}$ and sampling was done daily for 0-4 days. The number of microbes in the fish broth were counted using total plate count method after incubation at the temperature of $37^{\circ} \mathrm{C}$ for $24 \mathrm{~h}$. Each test was performed with 3 repetitions using factorial Randomized Design with 2 factors (SPL extract concentration and storage duration).

Antibacterial activity in minced fish was conducted by following Abdollahzadeh et al. (2014) method. A total of 2 $\mathrm{g}$ of minced fish was put into a sealed via (volume $15 \mathrm{~mL}$ ), the fish surface was manually flattened, and sterilized. Fresh culture (initial population $\pm 10^{6} \mathrm{CFU} / \mathrm{mL}$ ) was inoculated onto the fish surface and stored at room temperature for $30 \mathrm{~min}$. $1 \mathrm{~mL}$ of DSP ethanol extract solution at concentrations of $0,1,3$ and 5 MIC was then pipetted onto the inoculated surface. Incubation was done in the refrigerator at temperatur of $5^{\circ} \mathrm{C}$, sampling was done daily for 0 to 4 days. The number of bacteria was calculated by total plate count method after incubation at $37^{\circ} \mathrm{C}$ for $24 \mathrm{~h}$. The experiment were conducted three times. Application on the minced fish were conducted using factorial experiments in Completely Randomized
Design (factor 1: concentration of SPL extract, Factor 2: storage duration).

\section{Observation of $\boldsymbol{B}$. cereus cell's protein profile}

Fresh culture of $B$. cereus was washed twice using PBS, then the pellets were resuspended using PBS to obtain bacteria population density of $10^{7} \mathrm{CFU} / \mathrm{mL}$. Ethyl acetate fraction and water fraction of SPL were added into the bacterial suspension (each with the concentration of 0,1 and $3 \mathrm{MIC}$ ). After $2 \mathrm{~h}$ of exposure, the sample was centrifuged at $10,000 \mathrm{rpm}$ for $5 \mathrm{~min}$, and then the supernatant was discarded. Cell pellets were rinsed twice and resuspended using PBS. The obtained pellet were prepared and then run on gel electroforesis (SDS-PAGE) as previously performed by Wang et al. (2015)

\section{Observation of $B$. cereus cells' morphology transformation}

Bacterial pellets was prepared similarly as in the observation of the cell bacteria's protein profile. The morphology of cell pellets were observed using JEOL JSM-6360LA SEM (Scanning Electron Microscopy) as previously conducted by Miksusanti et al. (2009).

\section{Data analysis}

Data of DIZ and the number of bacteria ( $\log _{10}$ CFU) of each treatment analyzed using one and two way ANOVA using the SAS Statistical Program version 9.1. If any significant difference between treatments appeared, Duncan multiple range test (DMRT) were performed with the test level of $\alpha=5 \%$.

\section{RESULT AND DISCUSSION}

\section{Antibacterial activity of S. pinnata leaves}

The antibacterial activity of SPL ethanol extract and fractions against $B$. cereus and $V$. parahaemolyticus are shown in Table 1. The ethyl acetate fraction had higher antibacterial activity against $B$. cereus than other fractions (P-value $<0.05)$. Antibacterial activities of ethyl acetate fraction, water fraction and ethanol extract against $V$. parahaemolyticus were higher than other two fractions $(\mathrm{P}$ value $<0.05$ ). Chung and Yoon (2008) reported that ethyl acetate fraction of green tea had the highest inhibition zone against $B$. subtilis $(17.5 \mathrm{~mm})$ and $V$. parahaemolyticus $(25.5 \mathrm{~mm})$ when compared with water, hexane and chloroform fractions. High antibacterial activity in extract/fraction of semi-polar and polar fraction of SPL probably associated with its high phenol and flavonoid content. Ethyl acetate fraction and water fraction of $S$. pinnata fruit exocarp were reported to contain higher total phenol and flavonoids than hexane and dichloromethane fractions (Manik et al., 2013). Similarly, ethanol extract and ethylacetate extract of $S$. pinnata leaf were found to have higher total phenol and flavonoid content than those found in hexane extract (Jain et al., 2014). 
Antibacterial activity of SPL fraction ( $n$-hexane, chloroform, ethyl acetate and water) againts $B$. cereus was higher than $V$. parahaemolyticus. These results were supported by Bulbul (2016) who reported that antibacterial activity of ethyl acetate fraction of Momordica charantia leaves against $B$. cereus was higher $(20 \mathrm{~mm})$ than $V$. parahaemolyticus (17 $\mathrm{mm}$ ). Efdi et al. (2015) reported that ethyl acetate fraction of Enicosanthum membranifolium and Enicosanthum cupulare providing greater inhibition to $B$. cereus (MIC 0.25 and $0.125 \mathrm{mg} / \mathrm{mL}$ respectively) than V. parahaemolyticus (MIC 2 and $>4 \mathrm{mg} / \mathrm{mL}$ respectively). Shan et al. (2007) found that 46 herbal extracts and spices have greater inhibition impact in Gram positive bacteria rather than in Gram negative ones. Similarly, Santos et al. (2013) found that Gram negative bacteria are more resistant to the extract of Anacardium occidentale bark and leaves than those of Gram positive bacteria.
According to Lambert (2002), the difference in sensitivity between Gram-positive and Gram-negative bacteria to the extract could associate with differences in structure and composition of cell wall membrane between the two groups. The cell wall structure of Gram-positive bacterial consist of peptidoglycan and have a character. The Gramnegative bacteria have an outer membrane (OM) which is a barrier to small hydrophilic molecules penetration. There is a double external defense system, consists of peptidoglycan as well as OM containing various proteins and lipopolysaccharides (LPS). LPS consists of lipid A, the core polysaccharide, and the $O$ side chain, which provides the "quid" that allows Gram-negative bacteria to be more resistant to natural extracts with antimicrobial activity. OM can not be bypassed by hydrophobic or antibacterial antibiotics (Nazzaro et al., 2013).

Table 1: Antibacterial activity of ethanol extract and S. pinnata leaves' fractions.

\begin{tabular}{|c|c|c|c|c|}
\hline \multirow[t]{2}{*}{ Type of extract/fraction } & \multicolumn{2}{|l|}{ B. cereus } & \multicolumn{2}{|c|}{ V. parahaemolyticus } \\
\hline & $\mathrm{DIZ}(\mathrm{mm})^{1}$ & $\mathrm{MIC}^{2}$ & $\mathrm{DIZ}(\mathrm{mm})^{1}$ & $\mathrm{MIC}^{2}$ \\
\hline Ethanol extract & $8.40 \pm 1,61^{\mathrm{c}}$ & 3.12 & $11.47 \pm 3,41^{a}$ & 3.12 \\
\hline $\mathrm{n}$-Hexane fraction & $3.58 \pm 1,40^{e}$ & - & $2.99 \pm 1,42^{b}$ & - \\
\hline Chloroform fraction & $5,3 \pm 1,04^{d}$ & - & $5.29 \pm 1,16^{b}$ & - \\
\hline Ethyl acetate fraction & $13.43 \pm 0,39^{a}$ & 0.63 & $12.71 \pm 0,73^{a}$ & $>5.00$ \\
\hline Water fraction & $11.47 \pm 0.43^{b}$ & 0.63 & $10.48 \pm 0,18^{a}$ & 1.25 \\
\hline Chloramphenicol & $21.13 \pm 0.06$ & 0.01 & $37.70 \pm 0.11$ & 0.01 \\
\hline
\end{tabular}

The value in the same column that are not sharing the same superscript letter are significantly different from each other $(\mathrm{P}$-value $<0.05)$. ${ }^{1}$ clear zone diameter after substraction of well diameter is $6 \mathrm{~mm} ;{ }^{2} \mathrm{MIC}=$ Minimum Inhibition Concentration in $\mathrm{mg} / \mathrm{mL}$; -, not measured because of relatively small DIZ; DIZ, Diameter of Inhibition Zone.

\section{Stability of ethanol extract of S. pinnata leaves to $\mathrm{pH}$ $\mathrm{NaCl}$ and temperature}

Many factors might influence the ability of antimicrobial compounds to inhibit microbial growth, for examples $\mathrm{pH}$, temperature, and Aw (Naidu, 2000). Figure 1 shows the stability of the SPL ethanol extract to inhibit the growth of $B$. cereus and $V$. parahaemolyticus when it was challenged with $\mathrm{pH}$ variation, $\mathrm{NaCl}$ addition, and temperature variation. Antibacterial activity of SPL ethanol extract againsts $B$. cereus at $\mathrm{pH} 4$ was higher than that at $\mathrm{pH} 7$ (P-value $<0.05)$, but insignificant againsts $V$. parahaemolyticus at both $\mathrm{pH}$ (P-value $>0.05) . \quad \mathrm{NaCl}$ concentration (up to 10\%) in the extract did not affect the extract inhibition activity $(P$-value $>0.05)$ but heating of the extract up to $121{ }^{\circ} \mathrm{C}$ increased the extract's inhibition activity $(\mathrm{P}$-value $<0.05)$.

Study of $\mathrm{pH}$ effect on the antibacterial activity of Mangifera indica (Anacardiaceae) leaf extract by Doughari and Manzara (2008) was similar to the results of this study. Antibacterial activity of this extract at $\mathrm{pH} 8$ was 4 $\mathrm{mm}$ and increased to $9 \mathrm{~mm}$ at $\mathrm{pH} 5$ against $B$. cereus. The compond found in $S$. pinnata was not stabil in high $\mathrm{pH}$. In a low $\mathrm{pH}$, especially acid as gallic acid which found in S. pinnata (Chaudhuri et al., 2015) was undissociated form that means have a potential than in than dissociated form (Naidu 2000).
An increased in antibacterial activities after heating were also found by Doughari and Manzara (2008). Antibacteria activity of mango leaf extract againsts $B$. cereus increased when it was heated at temperature of 60 and $100{ }^{\circ} \mathrm{C}$ (from DIZ $11 \mathrm{~mm}$ to DIZ $13 \mathrm{~mm}$ ). In some cases, this might associate with an increase in phenolics content due to heating treatment. Xu et al. (2007) found the extract ethanol of orange peels heated at the temperature of 90,120 and $150{ }^{\circ} \mathrm{C}$ for $30 \mathrm{~min}$ and $120^{\circ} \mathrm{C}$ for 60 and 90 min resulting in an increase of free fraction of phenolic acid, while the ester, glycoside, and esterbound fractions decreased. Heating treatment to some extent might accelerate the release of phenolics compounds from its matric in plant extract.

During fish processing, SPL were utilized in an intact form, therefore ethanol extract were used to test the stability and effectiveness in the treatment and its application to fishes. Food structure and composition are very influential toward antibacterial activities. Population data of $B$. cereus and $V$. parahaemolyticus bacteria in fish broth and minced fish administered with SPL extract at some level of concentrations and stored at the temperature of $5^{\circ} \mathrm{C}$ is presented in Table 2.

The bactericidal effects of SPL ethanol extract against $B$. cereus and $V$. parahaemolitycus in fish broth were observed at 3 and $1 \mathrm{MIC}$, respectively. The effect was more apparent in fish broth rather than in fish flesh. It was reported that the combination of ginger and galangal 
essential oils inhibited more in the chicken broth than the chicken meat against $B$. cereus and $S$. Typhimurium (Rialita, 2014). Fish meat is a more complex medium with a more dense surface. Application of SPL ethanol extract to the minced fish gave bacteriostatic effect to both tested bacteria $(\mathrm{P}$-value $<0.05)$. The exposure of $5 \mathrm{MIC}$ of SPL extract for 4 days at $5{ }^{\circ} \mathrm{C}$ caused the decrease in population of $B$. cereus and $V$. parahaemolyticus by 0.77 and $1.86 \mathrm{CFU}$ logs (compared to 0 day and $0 \mathrm{MIC}$ ) respectively.
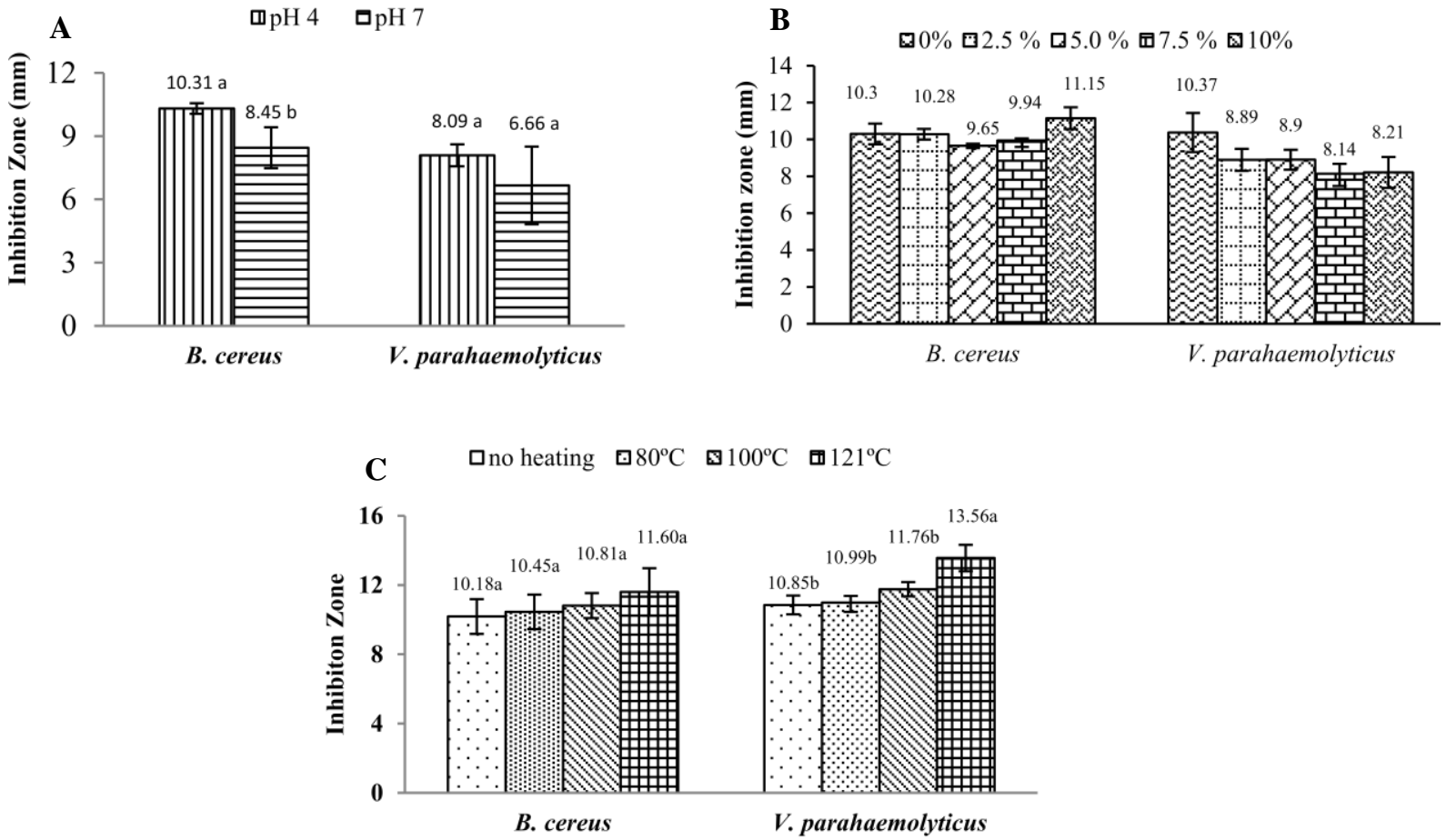

Figure 1: Inhibition zone of ethanol extract at various $\mathrm{pH}(\mathrm{A})$ and $\mathrm{NaCl}$ levels (B) and temperature of heating (C) againsts $B$. cereus and $V$. parahaemolyticus.

Table 2: Population of $B$. cereus and $V$. parahaemolitycus bacteria in fish broth (log CFU/mL) and minced fish (log $\mathrm{CFU} / \mathrm{g}$ ) exposed to SPL ethanol extract.

\begin{tabular}{|c|c|c|c|c|c|c|c|c|}
\hline \multirow{2}{*}{ Days } & \multicolumn{4}{|c|}{ Fish broth + extract (MIC) } & \multicolumn{4}{|c|}{ Minced fish +extract (MIC) } \\
\hline & 0 & 1 & 3 & 5 & 0 & 1 & 3 & 5 \\
\hline \multicolumn{9}{|c|}{ B. cereus } \\
\hline 0 & $6.50 \pm 0.15$ & $6.17 \pm 0.09$ & $<1.00$ & $<1.00$ & $6.67 \pm 0.06^{b c}$ & $6.56 \pm 0.11^{\mathrm{c}}$ & $6.22 \pm 0.05^{\mathrm{efg}}$ & $6.17 \pm 0.05^{\mathrm{gh}}$ \\
\hline 1 & $6.04 \pm 0.00$ & $6.06 \pm 0.10$ & $1.72 \pm 0.48$ & $1.39 \pm 0.10$ & $6.95 \pm 0.03^{a}$ & $6.72 \pm 0.16^{b}$ & $6.27 \pm 0.04^{\text {defg }}$ & $6.07 \pm 0.07^{\mathrm{h}}$ \\
\hline 2 & $7.04 \pm 0.04$ & $7.10 \pm 0.40$ & $<1.00$ & $<1.00$ & $6.73 \pm 0.10^{\mathrm{b}}$ & $6.70 \pm 0.07^{\mathrm{bc}}$ & $6.41 \pm 0.08^{d}$ & $6.21 \pm 0.16^{\mathrm{fgh}}$ \\
\hline 3 & $7.07 \pm 0.08$ & $7.20 \pm 0.44$ & $<1.00$ & $<1.00$ & $6.88 \pm 0.01^{a}$ & $6.71 \pm 0.07^{\mathrm{bc}}$ & $6.39 \pm 0.01^{d}$ & $6.34 \pm 0.02^{\text {def }}$ \\
\hline 4 & $6.98 \pm 0.59$ & $6.34 \pm 0.55$ & $<1.00$ & $<1.00$ & $6.72 \pm 0.05^{\mathrm{b}}$ & $6.37 \pm 0.01^{\mathrm{de}}$ & $6.26 \pm 0.16^{\text {defg }}$ & $5.90 \pm 0.00^{i}$ \\
\hline \multicolumn{9}{|c|}{ V. parahaemolyticus } \\
\hline 0 & $5.33 \pm 0.19$ & $3.08 \pm 0.07$ & $<1.00$ & $<1.00$ & $5.66 \pm 0.05^{a}$ & $5.49 \pm 0.02^{\mathrm{abc}}$ & $5.47 \pm 0.05^{\mathrm{abc}}$ & $5.30 \pm 0.14^{\mathrm{abc}}$ \\
\hline 1 & $3.11 \pm 0.10$ & $<1.00$ & $<1.00$ & $<1.00$ & $5.52 \pm 0.02^{\mathrm{ab}}$ & $5.31 \pm 0.15^{\mathrm{abc}}$ & $5.21 \pm 0.13^{\mathrm{bcd}}$ & $5.11 \pm 0.05^{\mathrm{cde}}$ \\
\hline 2 & $3.11 \pm 0.09$ & $<1.00$ & $<1.00$ & $<1.00$ & $5.31 \pm 0.19^{a b c}$ & $4.64 \pm 0.21^{\dagger}$ & $4.84 \pm 0.18^{\text {def }}$ & $4.63 \pm 0.23^{\text {def }}$ \\
\hline 3 & $3.12 \pm 0.08$ & $<1.00$ & $<1.00$ & $<1.00$ & $4.75 \pm 0.17^{\text {ef }}$ & $4.69 \pm 0.29^{e f}$ & $3.83 \pm 0.08^{g}$ & $3.69 \pm 0.08^{9}$ \\
\hline 4 & $3.17 \pm 0.31$ & $<1.00$ & $<1.00$ & $<1.00$ & $4.76 \pm 0.24^{\mathrm{ef}}$ & $4.80 \pm 0.11^{\text {def }}$ & $3.90 \pm 0.05^{g}$ & $3.80 \pm 0.06^{\mathrm{g}}$ \\
\hline
\end{tabular}


Mal. J. Microbiol. Vol 14(5) 2018, pp. 393-400 http://dx.doi.org/10.21161/mjm.112117

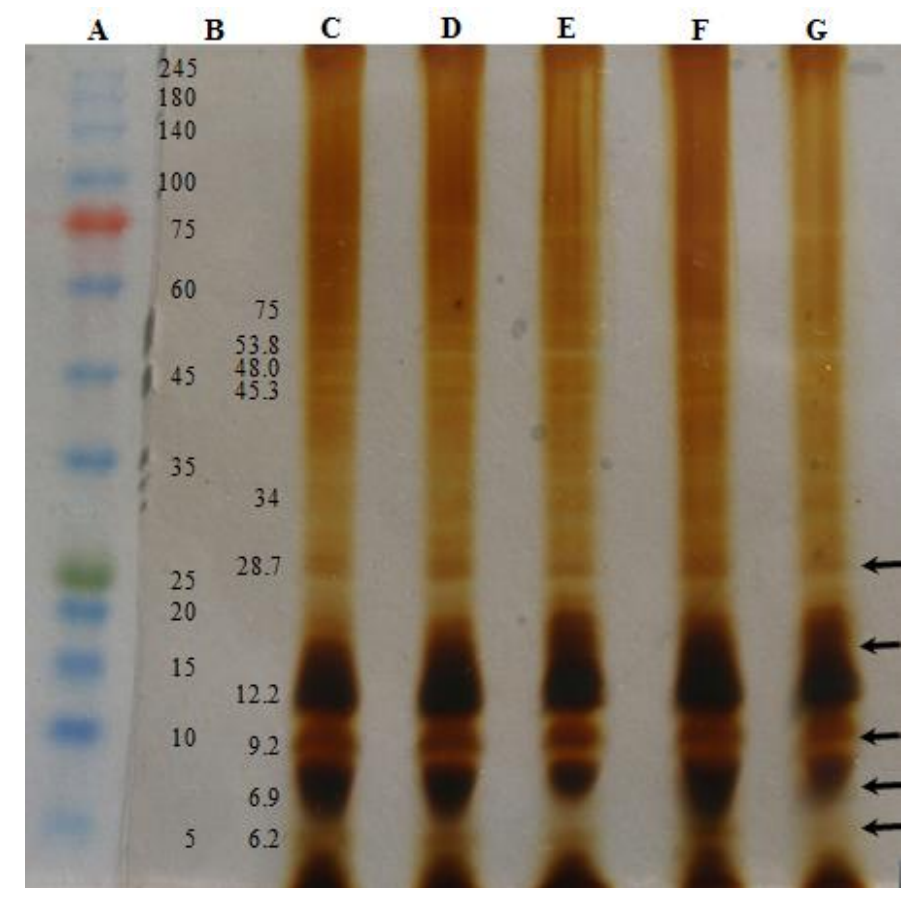

Figure 2: Protein profile of $B$. cereus cells using SDS-PAGE method (A, Marker; B, Protein molecular weight, kDa; C, Unexposed bacteria (0 MIC); Exposed bacteria: D, 1 MIC of ethyl acetate fraction; $\mathrm{E}, 3 \mathrm{MIC}$ of ethyl acetate fraction; $F, 1$ MIC of water fraction; G, 3 MIC of water fraction).
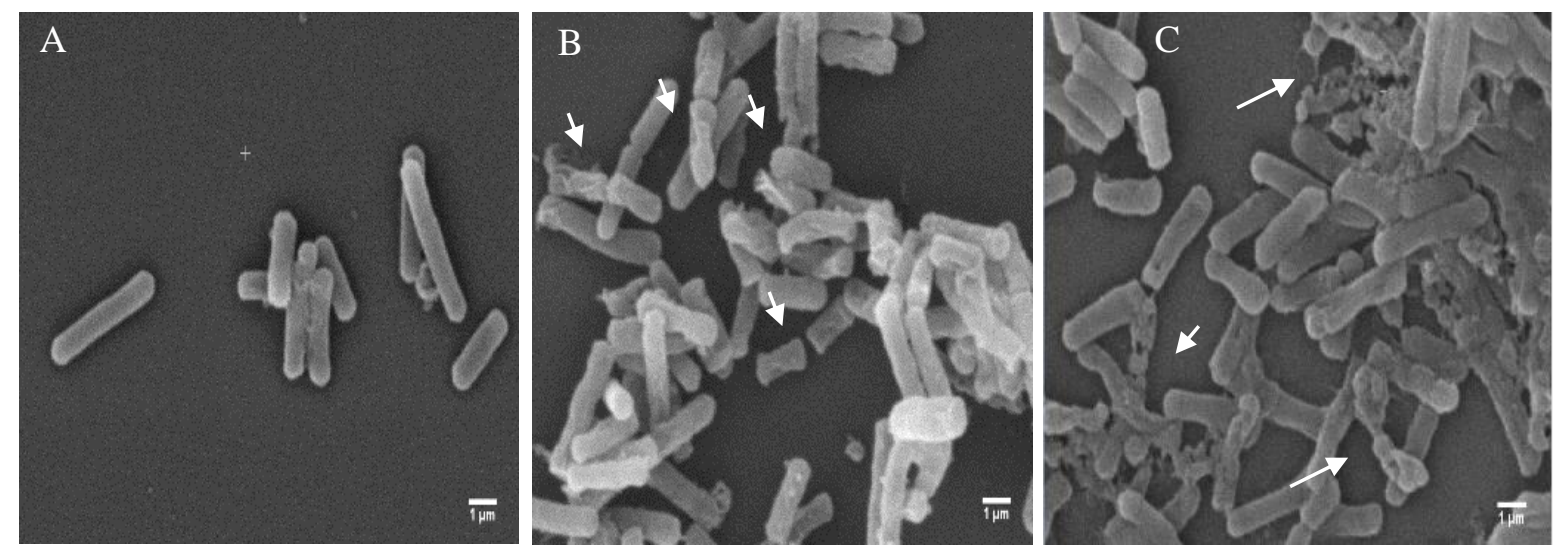

Figure 3: The morphology of $B$. cereus cells using SEM after $1 \mathrm{~h}$ of incubation in the PBS containing antibacterial (A, 0 MIC, control; B, 3 MIC ethyl acetate; C, 3 MIC water fraction; arrows indicate the damaged cells).

In Table 2, there was a decrease in the number of $V$. parahaemolyticus by 2.22 CFU logs in fish broth without SPL after 1 day incubation at $5{ }^{\circ} \mathrm{C}$. Whereas with $1 \mathrm{MIC}$ SPL (on the same medium), the number of the bacteria was $<1.00 \log$ CFU/mL after one day of incubation. The decline in bacterial population in this study, in addition to the presence of SPL Extract, also due to the use of low temperatures. According to Muntada-Garriga et al. (1995), $\checkmark$. parahaemolyticus will be inactive when stored at low temperatures. The inactivation time depends on the amount of the initial bacteria and the incubation temperature. Wang et al. (2008) found a decrease in the number of $V$. parahaemolyticus during storage at $5^{\circ} \mathrm{C}$ in live and slurry Jinjiang oyster and APW (alkaline pepton water) with the greatest decrease in the slurry ( $>2$ logs CFU, incubation time $<24 \mathrm{~h}$ ).

Protein profile of $B$. cereus cells exposed to ethyl acetate fraction and water fraction of $\mathrm{S}$. pinnata leaves 
Protein profile of $B$. cereus cells both unexposed and exposed to ethyl acetate fraction and water fraction is shown in Figure 2. There are differences of the protein bands thickness in the treated cells (D, E, F and $G$ ) as compared to the control group. It indicated that protein loss occured in $B$. cereus cells after being exposed to ethyl acetate and water fractions.

At the concentration of $3 \mathrm{MIC}$, protein bands of $B$. cereus cells are thinner as compared to those exposed under 0 and $1 \mathrm{MIC}$, especially the bands of $6.9,9.2$ and $28.7 \mathrm{kDa}$. Even the $6.2 \mathrm{kDa}$ protein bands were not visible at 3 MIC treatment. Wang et al. (2015) showed the differences of electrophoresis protein bands profile of Salmonella, E. coli and Listeria cells treated with lactic acid compared to the control group. In control group, the protein bands were greater in number and clearer in appearance, whereas in the lactic acid treatment, the protein bands were more vague and some even disappeared.

The morphology of $B$. cereus cell exposed to ethyl acetate fraction and water fraction of $S$. pinnata leaves

The morphological changes of $B$. cereus cells after being exposed to ethyl acetate and water fractions were observed using SEM. The result is shown in Figure 3. The ethyl acetate fraction-exposed there are many cells with defective cell wall ( $\mathrm{B}$, arrow), while destroyed cells are widely found in those exposed to water fraction (C, arrow).Miksusanti et al. (2009) demonstrated that after being exposed to Kaempheria pandurata essential oil, $B$. cereus cells showed rougher cell surface, multiplication of cell debris, and empty cells appearance under SEM. Polygonum cuspidatum root extracts was observed to cause morphological changes and damages to the cell wall of 6 tested bacteria including $B$. cereus (Shan et al., 2008). Damages to the cell wall and cytoplasmic membrane indicating the loss of membrane integrity and ability as permeability barrier, leading to cell death (Shan et al., 2008).

\section{CONCLUSION}

Ethanolic extract of $S$. pinnata leaves demostrated good antibacterial activities against $B$. cereus and $V$. parahaemolyticus with equal MIC value $(3.12 \mathrm{mg} / \mathrm{mL})$. After fractionation, ethyl acetate fraction had the highest antibacterial activity (MIC $0.63 \mathrm{mg} / \mathrm{mL}$ ) against $B$. cereus. The mechanism was proposed due to its ability to damage the cell wall. The ethanol extract of SPL was stable under $\mathrm{pH} 4$ and heating temperature up to $121^{\circ} \mathrm{C}$. At $3 \mathrm{MIC}$, it was more effective to inhibit $B$. cereus and $V$. parahaemolyticus in fish broth than in minced fish.

\section{REFERENCES}

[NACMCF]. (2008). Response to the questions posed by the Food and Drug Administration and the National
Marine Fisheries Service regarding determination of cooking parameters for safe seafood for consumers. Journal of Food Protection 6, 1287-1308.

Abdollahzadeh, E., Rezaei, M. and Hosseini, H. (2014). Antibacterial activity of plant essential oils and extracts: The role of thyme essential oil, nisin, and their combination to control Listeria monocytogenes inoculated in minced fish meat. Food Control 35, 177183.

Bulbul, I. J. (2016). Determination of antibacterial, antifungal and cytotoxic activities of n-hexane, chloroform and ethyl acetate extracts of Momordica charantia leaves. Pharma Tutor 4(3), 28-33.

Chaudhuri, D., Ghate, N. B., Singh, S. S. and Mandal, N. (2015). Methyl gallate isolated from Spondias pinnata exhibits anticancer activity against human glioblastoma by induction of apoptosis and sustained extracellular signal-regulated kinase 1/2 activation. Pharmacognosy Magazine 11, 269-276.

Chinnaiyan, S. K., Subramanian, M. R., Kumar, S. V., Chandu, A. N. and Deivasigamani, K. (2013). Antimicrobial and anti-HIV activity of extracts of Canthium coromandelicum (Burm. f.) Alston leaves. Journal of Pharmacy Research 7, 588-694.

Chung, S. H. and Yoon, K. H. (2008). Antimicrobial activity of extracts and fractions of green tea used for coarse tea. Journal of the Korean Society of Food Science and Nutrition 37(11), 1382-1388.

Davidson, M. P. (2001). Chemical preservatives and natural antimicrobial compounds, food microbiology. ASM Press, Washington DC (US). pp. 593-627.

Doughari, J. H. and Manzara, S. (2008). In vitro antibacterial activity of crude leaf extracts of Mangifera indica Linn. African Journal of Microbiology Research 2, 67-72.

Efdi, M., Koketsu, M., Watanabe, K. and Nurainas. (2015). Study on antimicrobial properties of Enicosanthum membranifolium Sinclair and Enicosanthum cupulare (King) Airy-Shaw. Jurnal Riset Kimia 3(1), 62-66.

Elhadi, N., Aljeldah, M. and Aljindan, R. (2016). Microbiological contamination of imported frozen fish marketed in Eastern Province of Saudi Arabia. International Food Research Journal 23, 2723-2731.

Jain, P., Hossain, K. R., Mishu, T. R. and Reza, H. M. (2014). Antioxidant and antibacterial activities of Spondias pinnata Kurz. leaves. European Journal of Medicinal Plants 4, 183-195.

Lambert, P. A. (2002). Cellular impermeability and uptake of biocides and antibiotics in Gram-positive bacteria and mycobacteria. Journal of Applied Microbiology Symposium Supplement 92, 46-54.

Manik, M. K., Islam, S. M. A., Wahid, M. A., Morshed, M. M, Kamal, S., Islam, M. S. and Ahmed, K. T. (2013). Investigation of in vitro antioxidant, antimicrobial and thrombolytic activity of the exocarp of Spondias pinnata (Anacardiaceae). Canadian Chemical Transactions 1(3), 191-201.

Maser, W. H., Yuliana, N. D. and Andarwulan, N. (2015). Rapid identification of antibacterial compounds 
from turkey berry by HPLC based metabolomics. Journal of Liquid Chromatography and Related Technologies 38(12), 1230-1235.

Miksusanti, Jenie, B. S. L., Syarief, R., Pontjo, B. and Mulyadi, G. T. (2009). Antibacteria activity of temu kunci tuber (Kaempheria pandurata) essential oil against Bacillus cereus. Medical Journal of Indonesia 18, 10-17.

Muhammad, A. (2013). Bioactivity guided isolation of active principles from Spondias pinnata of Bangladesh. Ph.D. Dissertation. University of Dhaka, BD.

Muntada-Garriga, J. M., RodriguezJerez, J. J., LopezSabater, E. I. and Mora-Ventura, M. T. (1995). Effect of chill and freezing temperatures on survival of Vibrio parahaemolyiicus inoculated in homogenates of oyster meat. Letters in Applied Microbiology 20, 225-227.

Naidu, A. S. (2000). Natural food antimicrobial system. CRC Press, Washington D.C (US). pp 11-12.

Naufalin, R., Jenie, B. S. L., Kusnandar, F., Sudarwanto, M. and Rukmini, H. S. (2006). Effect of $\mathrm{pH}, \mathrm{NaCl}$ and teating on the antibacterial stability of kecombrang (Nicolaia speciosa Horan) flower extracts and its aplication in minced meat). Journal of Food Technology and Industry 7, 197-203.

Nazzaro, F., Fratianni, F., De Martino, L., Coppola, R. and De Feo, V. (2013). Effect of essential oils on pathogenic bacteria. Pharmaceuticals 6, 1451-1474.

Noorlis, A., Ghazali, F. M., Cheah, Y. K., Tuan Zainazor, T. C., Ponniah, J., Tunung, R., Tang, J. Y. H., Nishibuchi, M., Nakaguchi, Y. and Son, R. (2011). Prevalence and quantification of Vibrio species and Vibrio parahaemolyticus in freshwater fish at hypermarket level. International Food Research Journal 18, 689-695.

Parhusip, A. J. N., Jenie B. S. L., Rahayu, W. P. and Yasni, S. (2005). Effect of andaliman (Zanthoxylum acanthopodium DC) extracts upon permeability and hidrophobicity of Bacillus cereus. Journal of Food Technology and Industry 16, 24-30.

Rialita, T. (2014). Antibacterial efficacy of combined Zingiber officinale var. Rubrum and Alpinia purpurata $\mathrm{K}$. Schum essential oils and its application on food model. Ph.D Dissertation. Bogor Agricultural University, ID.

Sadiq, M. B., Hanpithakpong, W., Tarning, J. and Anal, A. K. (2015). Screening of phytochemical and in vitro evaluation of antibacterial and antioxidant activities of leaves, pods and bark extract of Acacia nilotoca (L.) Del. Industrial Crops and Products 77, 873-882.

Santos, F. O., Angélico, E. C., da Costa, J. G. M., Rodrigues, F. F. G., Rodrigues, O. G. and de Medeiros, R. S. (2013). Antibacterial evaluation of Anacardium occidentale (Linn) (Anacardiaceae) in semiarid Brazil. African Journal of Biotechnology 12, 4836-4840.

Shan, B., Cai, Y. Z., Brooks, J. D. and Corke, H. (2007). The in vitro antibacterial activity of dietary spice and medicinal herb extracts. International Journal of Food Microbiology 117, 112-119.
Shan, B., Cai, Y. Z., Brooks, J. D. and Corke, H. (2008). Antibacterial properties of Polygonum cuspidatum roots and their major bioactive constituents. Food Chemistry 109, 530-537.

Wang, C., Chang, T., Yang, H. and Cui, M. (2015). Antibacterial mechanism of lactic acid on physiological and morphological properties of Salmonella Enteritidis, Escherichia coli and Listeria monocytogenes. Food Control 47, 231-236.

Wang, Y., Zhang, H. Y., Fodjo, E. K., Kong, C., Gu, R. R., Han, F. and Shen, X. S. (2018). Temperature effect study on growth and survival of pathogenic Vibrio parahaemolyticus in Jinjiang oyster (Crassostrea rivularis) with rapid count method. Journal of Food Quality 2018, (Retrieved date: 28 June 2018).

Xu, G., Ye, X., Chen, J. and Liu, D. (2007). Effect of heat treatment on the phenolic compounds and antioxidant capacity of citrus peel extract. Journal of Agricultural and Food Chemistry 55(2), 330-335. 